\title{
Sedimentation and Its Impacts/Effects on River System and Reservoir Water Quality: case Study of Mazowe Catchment, Zimbabwe
}

\author{
Colleta Tundu $^{1}$, Michael James Tumbare ${ }^{2}$, and Jean-Marie Kileshye Onema ${ }^{3}$ \\ ${ }^{1}$ Zimbabwe National Water Authority, P.O. Box Cy617 Causeway, Harare, Zimbabwe \\ ${ }^{2}$ Department of Civil Engineering, University of Zimbabwe, P.O. Box MP167, \\ Mt Pleasant, Harare, Zimbabwe \\ ${ }^{3}$ WaterNet Secretariat, P.O. Box MP600, Mount Pleasant, Harare, Zimbabwe
}

Correspondence: Colleta Tundu (ctundu@gmail.com)

Received: 7 June 2017 - Accepted: 10 October 2017 - Published: 16 April 2018

\begin{abstract}
Sediment delivery into water sources and bodies results in the reduction of water quantity and quality, increasing costs of water purification whilst reducing the available water for various other uses. The paper gives an analysis of sedimentation in one of Zimbabwe's seven rivers, the Mazowe Catchment, and its impact on water quality. The Revised Universal Soil Loss Equation (RUSLE) model was used to compute soil lost from the catchment as a result of soil erosion. The model was used in conjunction with GIS remotely sensed data and limited ground observations. The estimated annual soil loss in the catchment indicates soil loss ranging from 0 to $65 \mathrm{tha} \mathrm{yr}^{-1}$. Bathymetric survey at Chimhanda Dam showed that the capacity of the dam had reduced by $39 \%$ as a result of sedimentation and the annual sediment deposition into Chimhanda Dam was estimated to be $330 \mathrm{t}$ with a specific yield of $226 \mathrm{t} \mathrm{km}^{-2} \mathrm{yr}^{-1}$. Relationship between selected water quality parameters, TSS, $\mathrm{DO}, \mathrm{NO}_{3}, \mathrm{pH}$, TDS, turbidity and sediment yield for selected water sampling points and Chimhanda Dam was analyzed. It was established that there is a strong positive relationship between the sediment yield and the water quality parameters. Sediment yield showed high positive correlation with turbidity (0.63) and TDS (0.64). Water quality data from Chimhanda treatment plant water works revealed that the quality of water is deteriorating as a result of increase in sediment accumulation in the dam. The study concluded that sedimentation can affect the water quality of water sources.
\end{abstract}

\section{Introduction}

Sedimentation is a process whereby soil particles are eroded and transported by flowing water or other transporting media and deposited as layers of solid particles in water bodies such as reservoirs and rivers. It is a complex process that varies with watershed sediment yield, rate of transportation and mode of deposition (Ezugwu, 2013). Sediment deposition reduces the storage capacity and life span of reservoirs as well as river flows (Eroglu et al., 2010).

Sedimentation continues to be one of the most important threats to river eco-systems around the world. A study was done on the world's 145 major rivers with consistency long term sediment records and the results show that about $50 \%$ of the rivers have statistically a significantly downward flow trend due to sedimentation (Walling and Fang, 2003). Sumi and Hirose (2009) reported that the global reservoir gross storage capacity is about $6000 \mathrm{~km}^{3}$ and annual reservoir sedimentation rates are about $31 \mathrm{~km}^{3}(0.52 \%)$. This suggests that at this sedimentation rate, the global reservoir storage capacity will be reduced to $50 \%$ by year 2100 .

Studies on some dams in Zimbabwe show that reservoir capacities are being affected by sedimentation (Sawunyama et al., 2006; Dalu et al., 2013; Chitata et al., 2014).

Water is vital for all anthropogenic activities. Water bodies have been contaminated with various pollutants due to direct or indirect interference of men causing an adverse impact on human health and aquatic life (Lawson, 2011). The quality of 
water is getting vastly deteriorated due to improper land management and carelessness to the environment. Off late sediment transport in the water bodies has proved to be one of the major contributors to poor water quality. Due to land degradation and sheet erosion, the top soil is carried into the water bodies resulting in excess levels of turbidity. Silt and clay particles are primary carriers of adsorbed chemicals such as nitrogen and phosphorus.

This study uses the Mazowe Catchment area as a case study in analyzing river and reservoir sedimentation and its impact on water quality. Sedimentation in the rivers and reservoirs within the Mazowe Catchment area has become a major challenge for the policy makers as well as the water managers.

\subsection{Study area}

Mazowe Catchment is one of the seven water management catchments in Zimbabwe. It lies between $16.470^{\circ} \mathrm{S}$ (latitude) and $18.240^{\circ} \mathrm{S}$ (latitude) and between $30.680^{\circ} \mathrm{E}$ (longitude) and $33.000^{\circ} \mathrm{E}$ (longitude). The catchment has a total area of $38005 \mathrm{~km}^{2}$ and is in the northern part of the country. There are 30 major dams built along the main river and some of the tributaries. There are 13 functional gauging stations within the catchment. The catchment is composed of twentyfour (24) hydrological sub-zones. Rainfall for the Catchment averages $500 \mathrm{~mm}$ to $1200 \mathrm{~mm} \mathrm{yr}^{-1}$ while the mean annual runoff is $131 \mathrm{~mm}$ with a coefficient of variation $(\mathrm{CV})$ of $126 \%$ (Zinwa, 2009). There are 17 water quality monitoring sampling points within the catchment. Six (6) sampling water points were selected for the study, these points were selected basing on the continuity of the available data meaning to say the points had less missing gaps.

Chimhanda Dam, in Lower Mazowe Sub-Catchment, was chosen for the assessment of the levels of sedimentation in resevoirs. Chimhanda Dam is located on the confluence of Runwa and Mwera Rivers, which are tributaries of Mazowe River. The dam is located in hydrological sub zone, DM1 with latitude $16^{\circ} 40^{\prime}$, and longitude $32^{\circ} 06^{\prime}$. The dam was completed in 1988 with a design capacity of $5.2 \times 10^{6} \mathrm{~m}^{3}$ and covering a catchment area of $68.7 \mathrm{~km}^{2}$, which mainly consists of communal lands.

\section{Materials and methods}

\subsection{Data collection}

Remote sensing images of the study area were downloaded from Landsat TM 4-5, LandSat LE7 and LandSat 8 scene from the website (https://glovis.usgs.gov/) for paths 168-170 and rows 71-73 for the period, 2000, 2005, 2008 and 2014. The study period was selected basing on the major changes in land use and land cover as a result of the Zimbabwe land reform programme which started in year 2000 and peaking during year 2003. The composite map was obtained by glu-

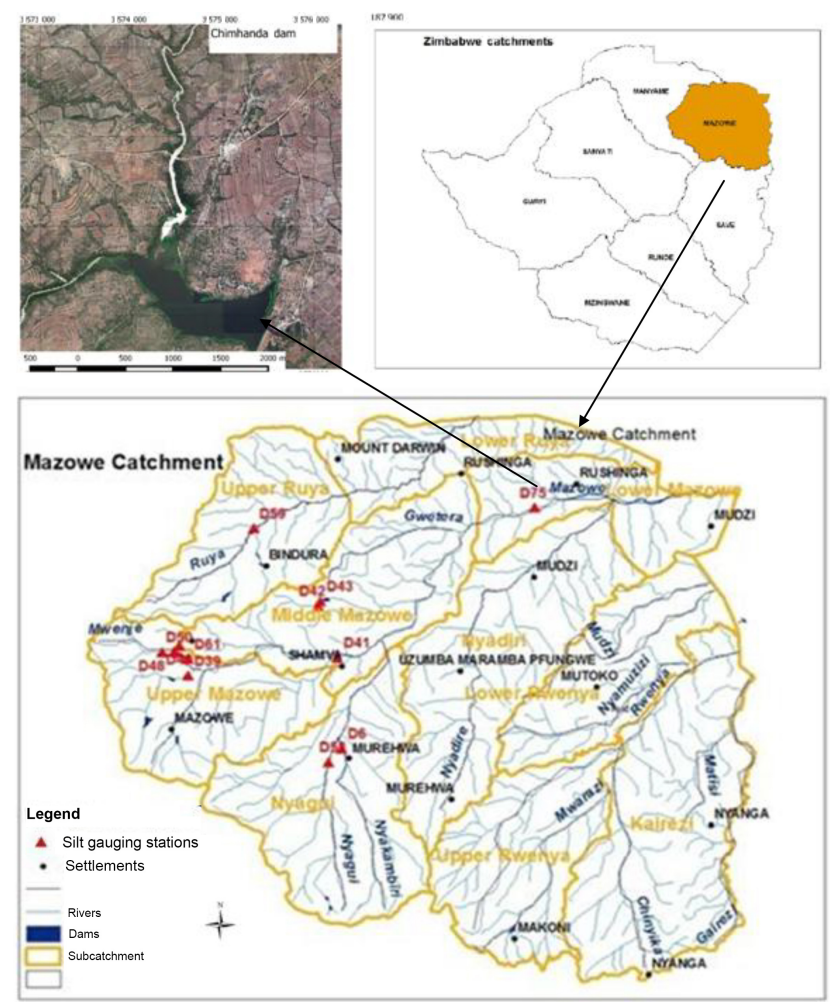

Figure 1. Mazowe Catchment and location of Chimhanda Dam.

ing and merging the tiles from the different scenes which was performed using Integrated Land and Water Information System (ILWIS) software. Normalized Differences Vegetation Index (NDVI) was extracted from the images and this was used to calculate the cover and management practice factor ( $C$ factor). SRTM DEM of $90 \mathrm{~m}$ resolution was obtained from Earth Explorer website (http://EarthExplorer.com). The DEM was used to calculate the slope length and slope steepness factor (LS factor). The erodibility factor was obtained from the soil map of Zimbabwe that was downloaded from website (www.fao.org/geonetwork. Rainfall data was obtained from the Zimbabwe Meteorological Services Department and was used to come up with the erosivity factor. The grab sample method was used to obtain samples for sediment loads from the flow gauges for the 2014/2015 rainfall season. Historical data for sediment loads from flow gauging stations were obtained from the Zimbabwe National Water Authority (ZINWA). Historical water quality data for selected water quality monitoring stations was obtained from Environmental Management Agency (EMA).

Siltation historical data for selected reservoirs within the catchment was obtained from ZINWA. A bathymetric survey was done to assess the level of sedimentation of Chimhanda dam which lies within the Mazowe Catchment. 


\subsection{Calculation of RUSLE Factors}

The Revised Universal Soil Erosion (RUSLE) model was used in this study to calculate the soil that was lost from the catchment. The model predicted the long term annual loss from the basin and is given by Eq. (1; Renard et al., 1997):

$A=R \times K \times \mathrm{LS} \times C \times P$

where: $A=$ annual soil loss (tha $\left.\mathrm{yr}^{-1}\right) ; R=$ rain erosivity factor $\left(\mathrm{MJ} \mathrm{mm} \mathrm{ha}^{-1} \mathrm{~h}^{-1}\right) ; K=$ soil erodibility factor ( $\left.\mathrm{thah} \mathrm{MJ}^{-1} \mathrm{~mm}^{-1}\right) ; \mathrm{LS}=$ slope length and slope steepness length $(\mathrm{m}) ; C=$ land cover and crop management; $P=$ management practice.

\subsubsection{Rain Erosivity Factor ( $R$ factor)}

Rainfall data was processed into average annual rainfall. Rain erosivity was calculated from the rainfall point map using Eq. (2; Merritt et al., 2003):

$R=38.5+0.35 \times P$

where: $R=$ Rain Erosivity Factor $\left(\right.$ Joule $\left.^{-2}\right) . P=$ Mean Annual Rainfall $\left(\mathrm{mm} \mathrm{yr}^{-1}\right)$.

\subsubsection{Soil Erodibility Factor ( $K$ factor)}

The soil erodibility factor ( $K$ Factor) was calculated using Eq. (3) with the parameters obtained from the soil map (Teh, 2011).

$K=\frac{\left(1.0 \times 10^{-4}\left(12-O M^{1.14}+4.5(F-3)+3.0(P-2)\right)\right.}{100}$

where $K=$ Soil Erodibility; $M=(\%$ fine sand $+\%$ fine sand) $] \times(100-\%$ clay) $O=\%$ of organic matter; $F=$ Soil Structure; $P=$ Permeability.

\subsubsection{Land Cover and Crop Management Factor ( $C$ factor)}

The $C$ factor was calculated using the Normalized Difference Vegetation Index (NDVI), which is a tool for assessing changes in vegetation cover (Pettorelli et al., 2005; Gusso et al., 2014). NDVI was calculated from the bands using Eq. (4; Deering, 1992).

$\mathrm{NDVI}=\frac{(\mathrm{NIR}-\mathrm{Red})}{(\mathrm{NIR}+\mathrm{Red})}$

where NIR = band 3 for landSat images 1 to 7 and band 4 for landSat 8 . Red $=$ band 4 for landSat 1 to 7 and band 5 for landSat 8 .

The calculated NDVI was then used to calculate the $C$ factor from Eq. (5)

$C$ factor map $=12708 \times \mathrm{NDVI}+02585$

\subsubsection{Management Practice Factor ( $P$ Factor $)$}

The $P$ factor reflects the control of conservation methods on soil loss. $P$ values range from 0.01 to 1 , with the value 0.01 being given to areas of maximum conservation support and the value 1 being given to areas with minimal or no conservation practices (Renard et al., 1997). The $P$ values were derived from the land use map of the study area. Different values were assigned to each type of land use as guided by literature and the $P$ factor map was produced (Jang et al., 1996).

\subsection{Quantifying the sediment yield in the Catchment}

The estimated soil loss was calculated from Eq. (6).

$A=R \times K \times \mathrm{LS} \times C \times P$

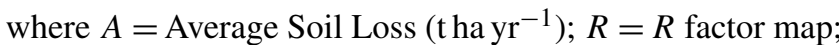
$K=K$ factor map; $\mathrm{LS}=\mathrm{LS}$ factor map; $C=C$ factor map; $P=P$ factor.

Soil loss from the catchment cannot be taken as sediment contribution to a river flow system since it does not account for deposition that occurs along the path (de Vente et al., 2011). Therefore the estimated soil loss was multiplied by the sediment delivery ratio (SDR) to obtain the sediment yield of the catchment. Sediment delivery ratios represent the fraction of the total soil loss that is washed into rivers and was calculated from using Eq. (7; USDA, 1972).

$\mathrm{SDR}=05656 \mathrm{CA}^{-0.11}$

where $\mathrm{SDR}=$ Sediment Delivery Ratio; $\mathrm{CA}=$ Watershed Area, $\mathrm{km}^{2}$.

After determination of the sediment delivery ratio, the average sediment yield was determined using Eq. (8), by Wischmeier and Smith (1978)

$\mathrm{SR}=\mathrm{SDR} \times A$

where: $\mathrm{SR}=$ Sediment yield $\left(\mathrm{t}_{\text {ha }} \mathrm{yr}^{-1}\right) ; \mathrm{SDR}=$ Sediment delivery ratio; $A=$ Average soil loss (tha $\mathrm{yr}^{-1}$ ).

\subsection{Sediment yield from field measurements}

Seven out of the thirteen functional ZINWA gauging stations were selected for collection of sediment concentration samples, (Fig. 2). Water samples were collected from various flow gauging stations for the period November 2014 to March 2015 using grab sampling method. An average of 20 samples was collected from each gauging station. The samples were analyzed in a laboratory using the weighing and filtration method inorder to determine the sediment concentration in $\mathrm{mg} \mathrm{L}^{-1}$. The sediment load was determined by multiplying the sediment load at a particular gauge by the area of influence. 


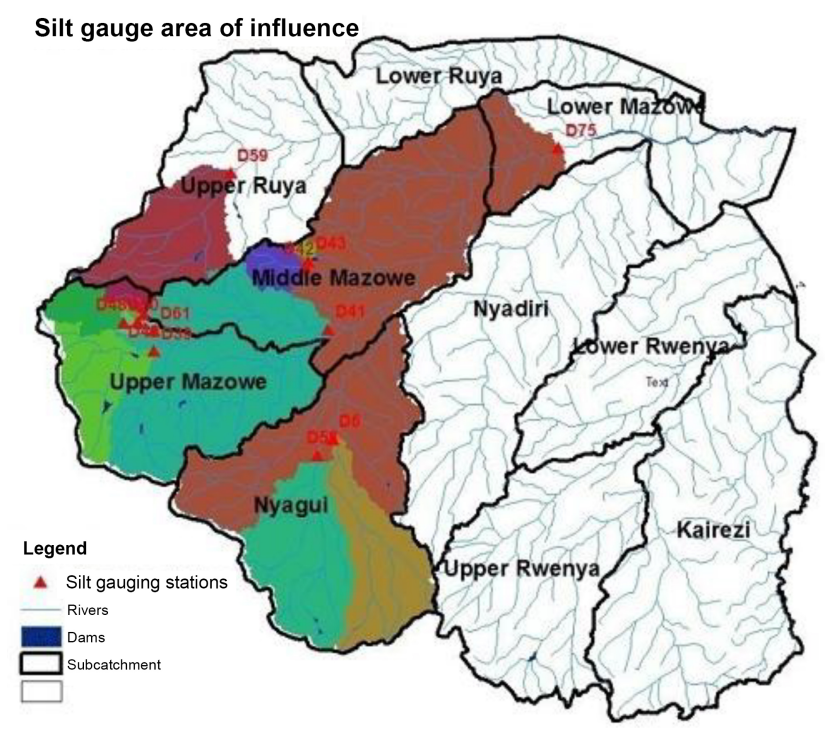

Figure 2. Gauges in the catchment and areas of influence.

\subsection{Assessing the current sedimentation levels of Chimhanda Dam}

A bathymetric survey was carried out at Chimhanda dam to determine the siltation level of the dam. The survey was conducted using a SonTek River Surveyor system and a theodolite to come up with a basin survey map. The plotted map was digitized to get the surface area between contours. The area was then multiplied by the contour interval to get the volume of each contour using Simpson's formula.

$V_{\text {contour }}=\frac{A_{1}+\left(A_{1} \times A_{2}\right)^{1 / 2}+A_{2}}{3}$

where $V_{\text {contour }}=$ contour Volume $\left(\mathrm{m}^{3}\right) ; A_{1}=$ Area $_{1}\left(\mathrm{~m}^{2}\right)$; $A_{2}=\operatorname{Area}_{2}\left(\mathrm{~m}^{2}\right)$.

The calculated volumes for each contour were accumulated to get the new capacity of the dam.

\subsection{Water quality trend from sedimentation}

Water quality historical data from six selected water sampling points were obtained from the Environmental Management Agency records. The points were selected basing on the consistency of the data and less gaps. The trend for the selected water quality parameters, TSS, $\mathrm{DO}, \mathrm{NO}_{3}, \mathrm{pH}$, TDS and turbidity for the corresponding predicted sediment yield years were analysed. The water quality parameters were compared with the Environmental Management Agency, Effluent and Solid Waste Disposal Regulations Statutory Instrument number 6 of 2007 (EMA, 2007) shown on Table 1. Water quality data for Chimhanda water supply treatment plant from the Zimbabwe National Water Authority was also related to the change in level of sedimentation of Chimhanda Dam.

\subsection{Investigation the relationship between sedimentation and water quality}

Selected water quality parameters were correlated with the corresponding sediment yield to determine the relationship between sediment yield and water quality. Pearson Correlation was used to estimate the strength of relationship between sediment yield and some physical water quality.

\section{Results and discussions}

\subsection{Results of the RUSLE factors}

The erosivity map ( $R$ factor) depicts rainfall energy in the various areas within the catchment. The rainfall erosivity ranges between 200 and $500\left(\mathrm{MJ} \mathrm{mm} \mathrm{ha}^{-1} \mathrm{~h}^{-1} \mathrm{yr}\right)$. A greater part of the catchment is averaging a rainfall erosivity value of $276 \mathrm{MJ} \mathrm{mm} \mathrm{ha}^{-1} \mathrm{~h}^{-1}$ yr. Highest rainfall erosivity values are in the Kairezi sub-catchment of the study area. Erodability ( $K$ factor) values range from 0 to $0.5 \mathrm{tha}^{-1} \mathrm{yr}^{-1} \mathrm{MJ}^{-1} \mathrm{~mm}^{-1}$. Some parts in the south west of the catchment have high values of erodibility, the highest $K$ value is dominated by very fine sand with silt particles which give rise to higher soil erodibility (Kamaludin et al., 2013). Highest slope length steepness (LS) values of $16 \mathrm{~m}$ were found in the eastern part of the catchment. The northern part of the catchment experiences average LS values of $7 \mathrm{~m}$.

Cover Management and Practice ( $C$ factor) ranges from -1 to 1 . The $C$ factor is depicted by NDVI which is a function of photosynthesis. The $C$ factor is high in the eastern highlands area, some parts of Kairezi sub-catchment and along the Mufurudzi area. This is possible because the Kairezi area experiences high rainfall while Mufurudzi being a game park, has more vegetation. High $C$ values were observed with high vegetation cover (Pettorelli et al., 2005). The $P$ value of 1 was observed in Lower Mazowe and Upper Rwenya subcatchment areas respectively. Areas like Mufurudzi and parts of Kairezi experienced an average $P$ value of 0.8 .

\subsection{Soil loss from the catchment}

The average annual soil loss for the different years are shown on Fig. 3 and the temporal variation of actual soil loss is tabulated on Table 2.

The estimated soil loss from the catchment ranges from 0 to $203 \mathrm{tha} \mathrm{yr}^{-1}$. The estimated average soil loss is 54 tha $^{-1}{ }^{-1}$. The highest soil loss is being experienced in Middle Mazowe and Nyagui sub-catchments. High soil loss in Middle Mazowe sub-catchment can be associated with high gold panning activities in the Mazowe valley whilst in Nyagui sub-catchment, this can be associated with high crop farming activities in the area. When the soil is made loose, its structure is altered hence increase in erodibility. 
Table 1. Effluent and solid waste disposal regulations.

\begin{tabular}{|c|c|c|c|c|c|c|}
\hline \multirow{3}{*}{ PARAMETER } & \multicolumn{5}{|c|}{ BANDS } & \multirow{3}{*}{$\begin{array}{l}\text { Test } \\
\text { Methods }\end{array}$} \\
\hline & \multicolumn{2}{|c|}{ Blue } & \multirow[t]{2}{*}{ Green } & \multirow[t]{2}{*}{ Yellow } & \multirow[t]{2}{*}{ Red } & \\
\hline & Sensitive & Normal & & & & \\
\hline DO \% saturation & $>75$ & $>60$ & $>50$ & $>30$ & $>15$ & SAZS 573 \\
\hline Nitrates $\mathrm{NO}_{3} \mathrm{mg} \mathrm{L}^{-1}$ & $<10$ & $<10$ & $<20$ & $<30$ & $<50$ & \\
\hline $\mathrm{PH}$ & $6.0-7.5$ & $6.0-9.0$ & $5-6,9-10$ & $4-5,10-12$ & $0-4,12-14$ & SAZS 483 \\
\hline TDS & $<100$ & $<500$ & $<1500$ & $<2000$ & $<3000$ & SAZS 576, \\
\hline Turbidity (NTU) & $<5$ & $<5$ & & & & SAZS 478 \\
\hline TSS $\mathrm{mg} \mathrm{L}^{-1}$ & $<10$ & $<25$ & $<50$ & $<100$ & $<150$ & SAZS 478 \\
\hline
\end{tabular}
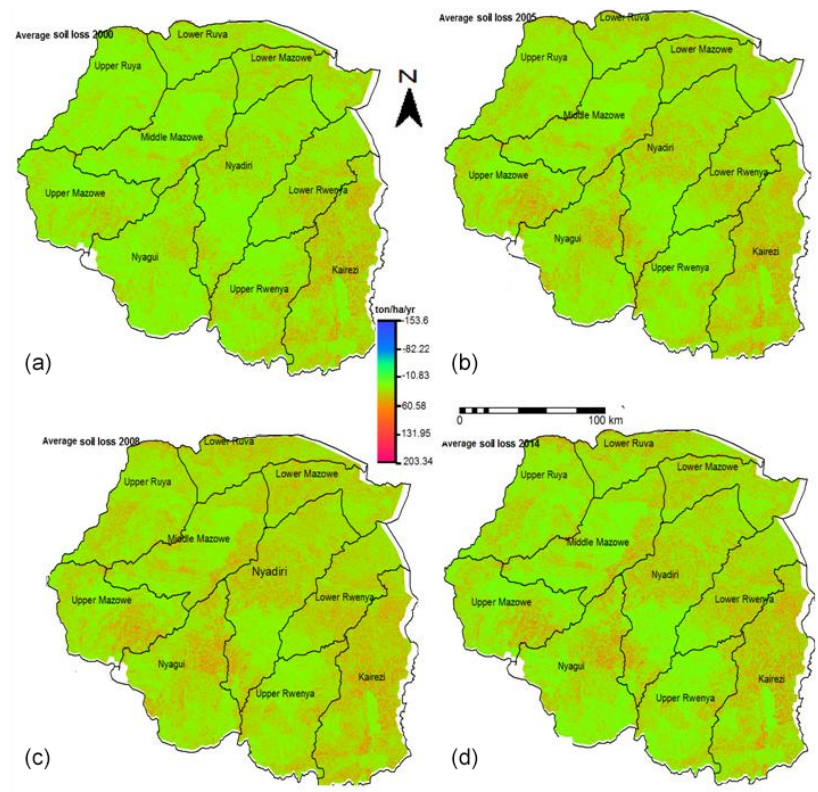

(b)

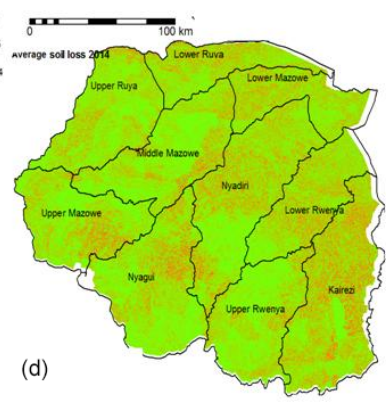

Figure 3. Estimated Average Soil Loss for 2000, 2005 2008, and 2014.

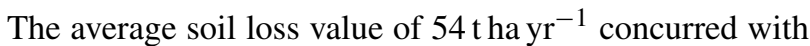
other studies that were carried out in the country. Whitlow (1986) found that $76 \mathrm{t}$ of soil is lost per hectare per year through soil erosion in most parts of the country. Another study by Mutowo and Chikodzi (2013) "Erosion hazards mapping in the Runde Catchment", concluded that most of the areas in the catchment fall in the category range of 0 50 tha $\mathrm{yr}^{-1}$. Makwara and Gamira (2012) reported that the most serious type of erosion being sheet erosion, is estimated

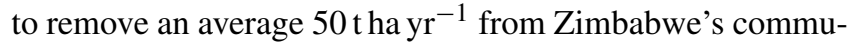
nal lands.

There is no uniform trend in the soil loss over the study period. In year 2000, the soil loss was $54 \mathrm{tha} \mathrm{yr}^{-1}$. The increase of soil loss in 2005 from the 2000 figure can be explained by the land reform programme which started in year 2000 and
Table 2. Temporal Variation of Estimated Soil Loss.

\begin{tabular}{rr}
\hline Year & $\begin{array}{r}\text { Average Soil } \\
\left.\text { Loss } \text { (tha yr }^{-1}\right)\end{array}$ \\
\hline 2000 & 54 \\
2005 & 65 \\
2008 & 36 \\
2014 & 62 \\
\hline
\end{tabular}

was at its peak around 2003. There was a lot of deforestation as new farmers were clearing land for agricultural purposes (Mambo and Archer, 2007). Some areas which were meant for animal rearing and forest were also converted to crop agricultural areas. In 2008 the soil loss rate decreased to $36 \mathrm{tha} \mathrm{yr}^{-1}$. The reduction can be attributed to a number of factors. Year 2008 experienced low erosivity as a result of low rainfall, which could also lead to low annual soil loss. The economy of Zimbabwe was almost at a stand-still during the period 2007 to 2009, with an inflation rate record of over 231 million percent in July 2008 (Hanke and Kwok, 2009). As a result there was less farming activities during that period.

The soil loss rate almost doubled in year 2014 as compared to 2008 . This can be explained by the increase in the number of small scale gold miners in the catchment and alluvial gold panning in streams and rivers. Mining within the catchment is not only limited to the river beds and banks, miners are also targeting the inland areas of the catchment such as the Mazowe Valley and Mufurudzi Game Park and as a result, soil erodibility is also increasing. Increase in rate of unemployment caused by low capital investment and continuing closure of industries in Zimbabwe has resulted in the population resorting to other sources of income such as illegal gold mining and alluvial gold panning. A study that was carried out in the Lower Manyame sub - catchment along Dande River, on the analysis of the implications of cross- sectional coordination of the management of gold panning activities 
Table 3. Measured sediment Load from flow gauges for the period December 2014 to March 2015.

\begin{tabular}{llrrr}
\hline Silt Gauge & Name or River & $\begin{array}{r}\text { Area of } \\
\text { Influence }\left(\mathrm{km}^{2}\right)\end{array}$ & $\begin{array}{r}\text { Sediment } \\
\text { load }\left(\mathrm{t} \mathrm{km}^{-2}\right)\end{array}$ & $\begin{array}{r}\text { Load } \\
(\mathrm{t})\end{array}$ \\
\hline D75 & Mazowe & 20380 & 1.4 & 28536 \\
D50 & Nyamasanga & 13 & 0.24 & 3 \\
D42 & Mupfurudzi & 163 & 1.92 & 313.56 \\
D41 & Mazowe & 3300 & 0.86 & 2836 \\
D6 & Shavanhowe & 1166 & 0.51 & 589.65 \\
D58 & Nyagui & 98.3 & 24.25 & 142.93 \\
D48 & Mwenje & 399 & 0.36 & 33.4 \\
\hline
\end{tabular}

Table 4. Summarized Results from the silt survey.

\begin{tabular}{lrrr}
\hline & 1988 & 2003 & 2015 \\
\hline Capacity at FSL $\left(\times 10^{6} \mathrm{~m}^{3}\right)$ & 5.2 & 3.470 & 3.194 \\
Loss Of Storage $(\%)$ & 0 & 33.3 & 38.6 \\
Dam Surface Area $(\mathrm{Ha})$ & 93.00 & 74.00 & 64.04 \\
\hline
\end{tabular}

and its impacts (Zwane et al., 2006), identified river bed gold panning activities as a cause of degradation of river channels and banks as well as accelerated erosion and siltation in many areas of Zimbabwe.

\subsubsection{Sediment Yield}

Figure 4 shows the sediment yield distribution map. Sed-

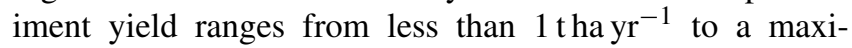

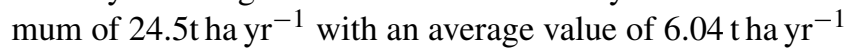
over the catchment area. The highest sediment yield is in the Middle Mazowe sub catchment area with an average

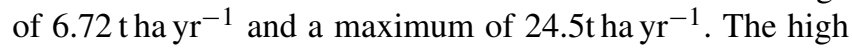
value can be associated with high gold panning activities in the Mazowe valley. The lowest value is in the Lower Ruya

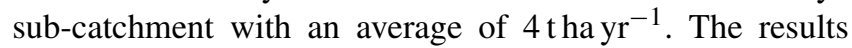
are almost in line with a study by Rooseboom and Engineers (1992) that estimated the average sediment yield in the nine defined sediment regions in Southern Africa to vary be-

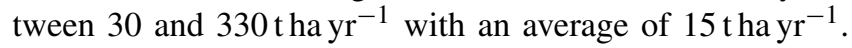
A study which was also carried out in the catchment area of Pahang River basin in Malasyia gave a sediment yield

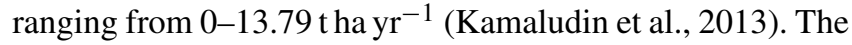
total sediment yield for the catchment was calculated to be 6.3 million $\mathrm{yr}^{-1}$.

\subsubsection{Measured Sediment Loads}

Results from the measured sediment loads were highest at D75 which is along Mazowe River, in the Zambezi valley. D41, located in Middle Mazowe sub catchment recorded a relatively high sediment load of $2836 \mathrm{t}$. D58 and D6 are both in Nyagui Sub-catchment recorded 142.93 and 589.65 t re-

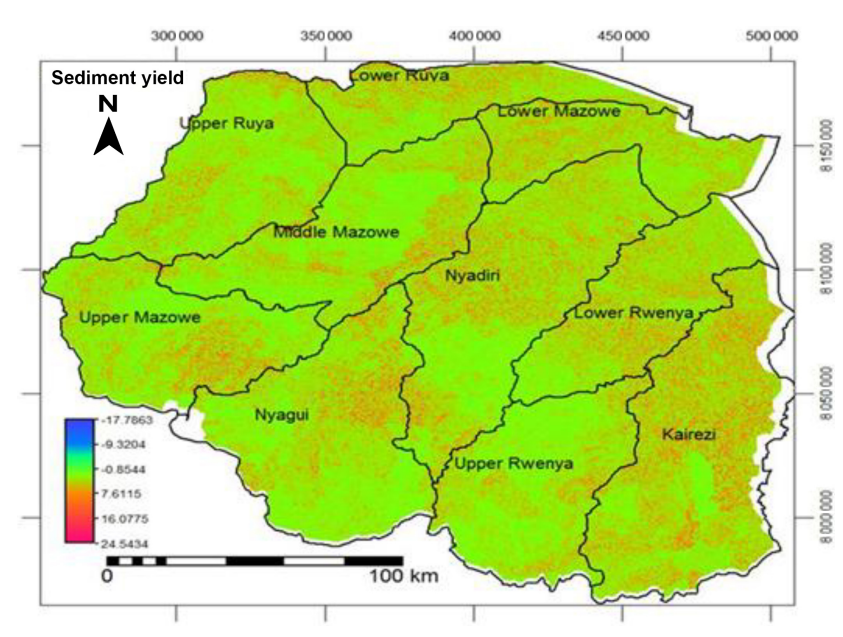

Figure 4. Sediment Yield within the Catchment.

Table 5. Results for the correlation between sediment yield and water quality parameters.

\begin{tabular}{llrrr}
\hline & & Sediment & $\begin{array}{r}\text { Ave } \\
\text { Turbidity }\end{array}$ & $\begin{array}{r}\text { Average } \\
\text { TSS }\end{array}$ \\
\hline \multirow{2}{*}{ Sediment } & & & .634 & .647 \\
& Pearson Correlation & 1 & .366 & .353 \\
& Sig. (2-tailed) & & .36 & 28 \\
\hline & N & & 28 & \\
\hline
\end{tabular}

spectively. D50, which is in Upper Mazowe sub catchment, recorded a low figure of $3 \mathrm{t}$. The results are concurring with those from RUSLE model, where high sediment yields were recorded from Middle Mazowe and Nyagui sub catchments respectively.

\subsection{Sedimentation in Chimhanda Dam from Bathymetric Survey}

Table 4 summarizes the results of the silt survey for Chimhanda Dam.

The capacity of the dam decreased from the original $5.200 \times 10^{6}$ to $3.470 \times 10^{6}$ and $3.194 \times 10^{6} \mathrm{~m}^{3}$ in years 2003 and 2015 respectively. There was $33.3 \%$ loss in stor- 


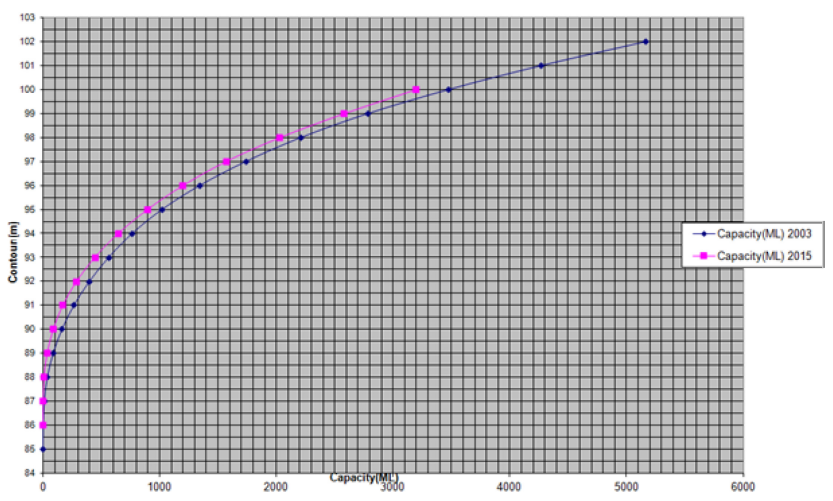

Figure 5. Chimhanda Dam Capacity comparison over the years.

age up to 2003 and a storage loss of $38.6 \%$ up to 2015 in reference to the design capacity. Figure 5 shows reservoir capacity changes over the years.

Results from the 10 samples of river inflows collected gave an average sediment concentration of $39 \mathrm{mg} \mathrm{L}^{-1}$. There was a decrease in trend in the sediment concentration as the rainfall season was progressing. The sediment accumulation in the reservoir was found to be $330 \mathrm{t} \mathrm{yr}^{-1}$ and the specific sediment yield was $226 \mathrm{t} \mathrm{km}^{-2} \mathrm{yr}^{-1}$. The usefulness of Chimhanda Dam has reduced from the initial design life of 50 to 37 years. A study by Godwin et al. (2011) on Chesa Causeway Weir in the same catchment gave a specific yield of $510 \mathrm{t} \mathrm{km}^{2} \mathrm{yr}^{-1}$. The usefulness of the dam was reduced from the initial design life of 50 to 25 years.

Generally the results support the existing literature that most of the small to medium dams are being affected by high rates of sedimentation in Zimbabwe (Sawunyama et al., 2006; Godwin et al., 2011; Dalu et al., 2013; Chitata et al., 2014).

\subsection{Water Quality Trend from Sedimentation}

Figures 6 to 10 show the results for the historically measured water parameters for the years 2000, 2008, 2010 and 2014.

\subsubsection{Turbidity}

Results for the years did not meet the permissible turbidity of 5 NTU. The highest turbidity values were recorded in 2000 and 2005 respectively. High values in 2005 corresponds to the high soil loss of $65 \mathrm{tha} \mathrm{yr}^{-1}$ that was recorded during that particular year. The high values in 2000 can be explained by high rainfalls that were experienced during that particular year as compared with the other years (Met, 2005). Low turbidity values were recorded during the year 2008, the same year recorded the lowest soil loss of $36 \mathrm{tha} \mathrm{yr}^{-1}$. High Turbidity levels are associated with poor water quality, (Adekunle et al., 2007). WHO (2008) highligted that high turbidity waters can facilitate the formation of nuclei, where gastrointestinal disease pathogens can attach. If that water

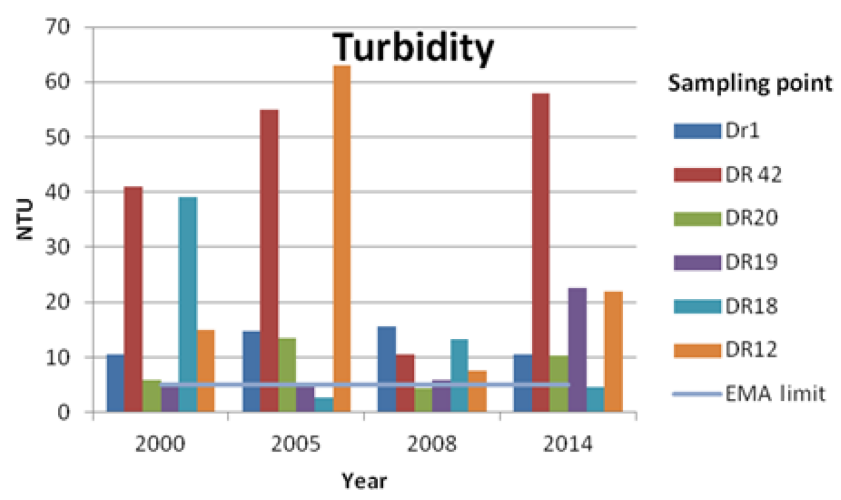

Figure 6. Turbidity variation among sampling points.

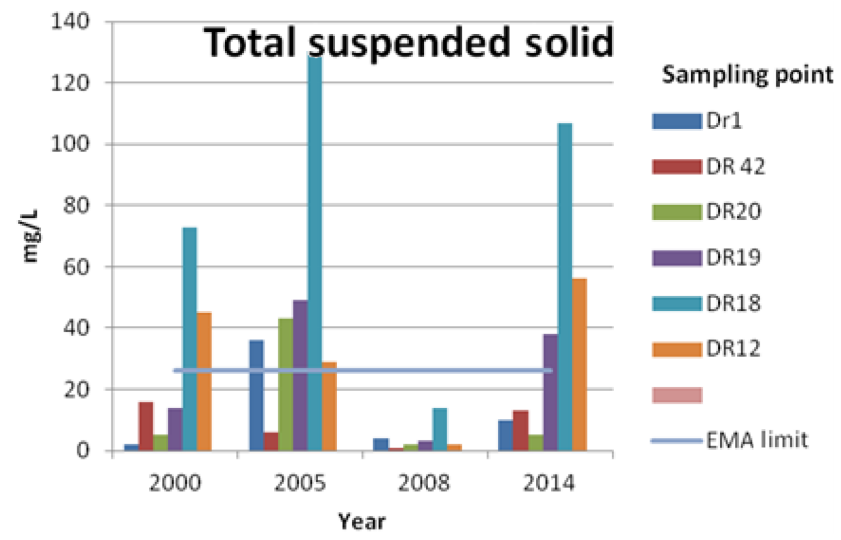

Figure 7. Total Suspended Solids variation among sampling points.

is consumed improperly treated, it can cause diseases. High turbidity leves also render the treatment of water expensive.

\subsubsection{Total Suspended Solids}

2008 values were below the recommended limit of $15 \mathrm{mg} \mathrm{L}^{-1}$ as shown on Fig. 7. High values were recorded during year 2000, 2005 and 2014. The high values are in agreement with the high soil loss that were recorded in those particular years. Total suspended solids are closely related to sedimentation (Chapman, 1996). When these suspended particles settles at the bottom of a water body they become sediments. Suspended solids consist of inorganic and organic fractions. Part of the organic fractions is bacterial and that might be detrimental to human health if the water is consumed without adequate treatment (Hoko, 2008).

\subsubsection{Dissolved Oxygen (DO)}

Dissolved Oxygen was above the lower limit for EMA at all the stations for all the years. Year 2000 and 2005 recorded $\%$ saturation of 125 and 100 respectively. Oxygen levels can be higher due to excess aquatic plants in the water which 


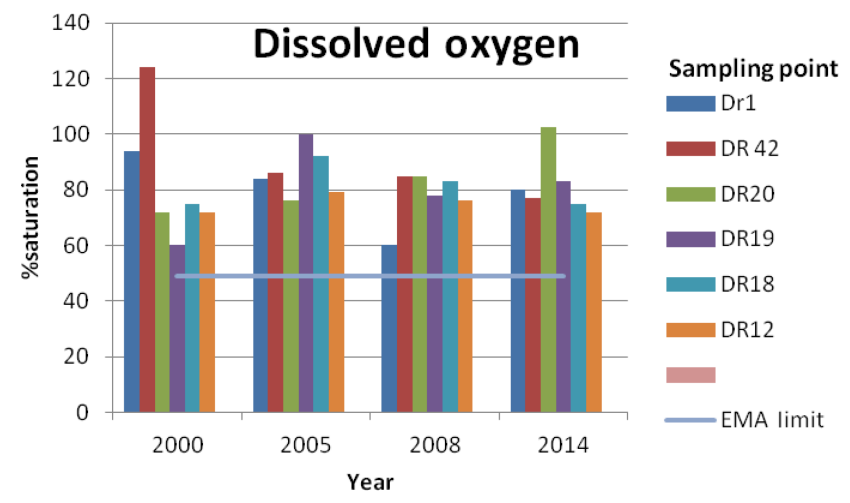

Figure 8. Dissolved Oxygen variation among sampling points.

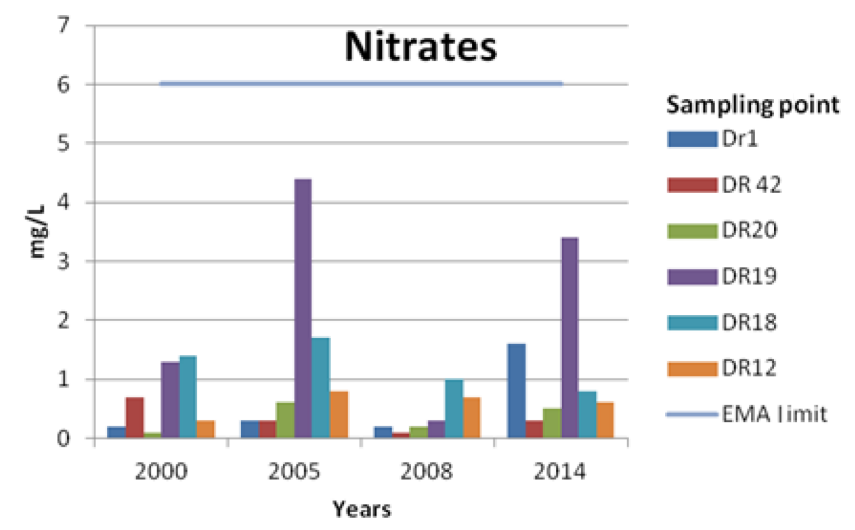

Figure 9. Nitrates variation along sampling points.

produce oxygen. Most living organisms require oxygen for their basic metabolic processes.

\subsubsection{Nitrates $\left(\mathrm{NO}_{3}\right)$}

Results for nitrates for the years under consideration were all below the recommended EMA levels of $6 \mathrm{mg} \mathrm{L}^{-1}$. Nitrates are washed by runoff from agricultural lands into water bodies. High concentration of nitrates in water bodies cause eutrophication, resulting in competition for oxygen by aquatic organisms and high water treatment costs (Dike et al., 2010).

\subsection{5 $\mathrm{PH}$}

$\mathrm{pH}$ values for all the years were within the normal limits category according to EMA upper and lower limits of 6 and 9 units respectively. Year 2005 had one sampling point that had a value slightly lower than the recommended. Bhadja and Vaghela (2013) indicated that activities in the water shed such as increased leaching of soils, soil erosion and heavy precipitation affects the $\mathrm{pH}$ levels downstream. $\mathrm{pH}$ levels as high as 9.0 and as low as 5 affects the life span of aquatic organisms (Addo et al., 2011). Low pH values do not have direct effect to human health, but can have indirectly effect

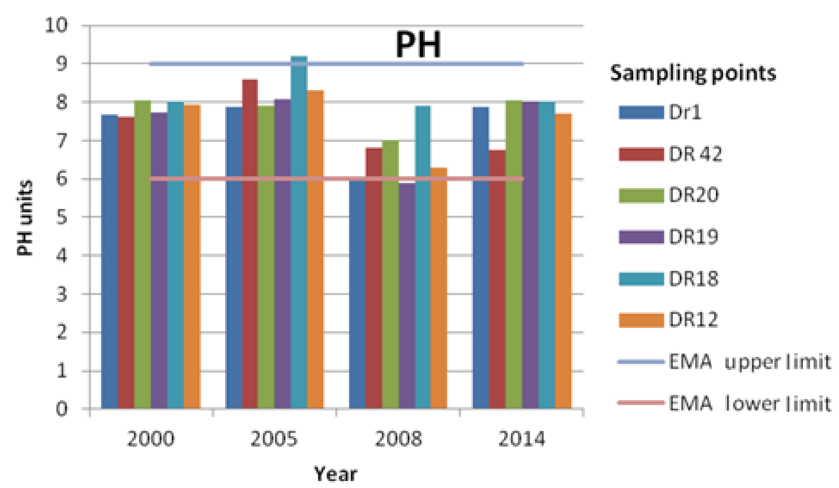

Figure 10. $\mathrm{pH}$ variations along sampling points.

since it causes leaching of metal irons such as copper, zinc and lead into the water (WHO, 2008).

\subsection{Relationship between sedimentation and river water quality}

Pearson correlation was used to determine the relationship between two water quality parameters and sediment yield. The parameters are related to sediment yield and these are turbidity and suspended solids, (Bhadja and Vaghela, 2013). The results are shown on Table 5.

There is a close positive relationship between turbidity and sediment yield of 0.63 . Total Suspended Solids have a positive relation of 0.64 . The results show that the two water quality parameters can be indicators of sedimentation. Higher values of total suspended solids and turbidity indicate higher values of sediment yield in water bodies.

\subsection{Variation in reservoir water quality}

The variation in two selected reservoir water quality indicators, turbidity and $\mathrm{pH}$ was determined. A significant variation in turbidity was noted for the years 1988 to 2014 with a $p$ value of 0.02 , which is less than 0.05 . The mean value of turbidity for 1988, 2003 and 2014 are 15.6, 34.4 and 41.7 NTU respectively. The values show an increasing trend in turbidity which may be as a result of anthropogenic activities occurring upstream of the dam which has resulted in increased soil erosion hence more sediment on the reservoir. $\mathrm{pH}$ results showed that there is no significant change between 1988 and 2014 ( $p$-value $>0.05$ ). This might be because $\mathrm{pH}$ is a chemical parameter that is determined by the type of sediments that are carried into the river not the sediment load. 


\section{Conclusions and recommendations}

\subsection{Conclusion}

The objective of the study was to analyze sedimentation and its impact on river system and reservoir water quality in Mazowe Catchment, Zimbabwe. The study's major findings are,

The catchment is generally experiencing moderate soil loss, however there are some pockets under high and extreme soil loss which gave rise to siltation and water quality deterioration of available water bodies.

There is reduction in capacity of reservoirs within the catchment due to sedimentation. Chimhanda Dam capacity has been reduced by $38.6 \%$ from the initial design capacity as of April 2015, reducing the usefulness of the dam to 37 years from the initial design life of 50 years due to siltation.

Sediment deposition in rivers affects water quality and water quality parameters can be used as an indicator for sedimentation.

\subsection{Recommendations}

In order to curb erosion and sedimentation in rivers and reservoirs, there is need to develop and implement an integrated water resources management plan by all stakeholders.

In order to maintain the lifespan of Chimhanda dam, best land management practices such as contour ploughing and re-forestation should be employed around the catchment area of the Dam and this is an area that could be considered for further research.

Data availability. The main data used in the research is rainfall data that was obtained from the meteorological department, water quality data obtained from Environmental management Agency as well as sediment Data from Zinwa. The data can be obtained from these departments.

Competing interests. The authors declare that they have no conflict of interest.

Special issue statement. This article is part of the special issue "Water quality and sediment transport issues in surface water". It is a result of the IAHS Scientific Assembly 2017, Port Elizabeth, South Africa, 10-14 July 2017.

Acknowledgements. This paper contains part of research results from the MSc Thesis of the corresponding author, Colleta Tundu, submitted to the University of Zimbabwe. Special thanks go to Faith Chivava for her assistance in GIS. ZINWA, EMA and the Zimbabwe Meteorological Services Department is appreciated for providing data.
Edited by: Akhilendra B. Gupta

Reviewed by: Rajendra Prasad and one anonymous referee

\section{References}

Addo, M. A., Okley, G. M., Affum, H.A., Acquah, S., Gbadago, J. K., Senu, J. K., and Botwe, B. O.: Water Quality and level of some heavy metals in water and sediments of Kpeshie Lagoon, La-Accra, Ghana, Research Journal of Environmental and Earth Sciences, 3, 487-497, 2011.

Adekunle, I. M., Adetunji, M. T., Gbadebo, A. M., and Banjoko, O. B.: Assessment of groundwater quality in a typical rural settlement in Southwest Nigeria, Int. J. Env. Res. Pub. He., 4, 307-318, 2007.

Bhadja, P. and Vaghela, A. : Assessment of Physico-Chemical parameters and water quality Index of reservoir water, International journal of plant animal and environmental sciences, 3, 89-95, 2013.

Chapman, D.: Water quality assessments - A guide to use of Biota, sediments and water in Environmental monitoring, 2nd Edn., Chapman and Hall, London, 191-193, 1996.

Chitata, T., Mugabe, F. T., and Kashaigili, J. J.: Estimation of Small Reservoir Sedimentation in Semi-Arid Southern Zimbabwe, Journal of Water Resource and Protection, 6, 48909, 12$14,2014$.

Dalu, T., Tambara, E. M., Clegg, B., Chari, L. D., and Nhiwatiwa, T.: Modeling sedimentation rates of Malilangwe reservoir in the south-eastern lowveld of Zimbabwe, Applied Water Science, 3, 133-144, 2013.

Dearing, J.: Sediment yields and sources in a welsh upland lakecatchment during the past 800 years, Earth Surf. Proc. Land., 17, 1-22, 1992.

de Vente, J., Verduyn, R., Verstraeten, G., Vanmaercke, M., and Poesen, J.: Factors controlling sediment yield at the catchment scale in NW Mediterranean geoecosystems, J. Soil. Sediment., 11, 690-707, 2011.

Dike, L., Keramat A., and Amirkolaie S.: Environmental impact of nutrient discharged by aquaculture waste water on the Haraz river, Journal of Agriculture and Biological Science, 3, 275-279, 2010.

EMA: Effluent and Solid Waste Disposal Regulations SI 6, of 2007, government printers of Zimbabwe, 2007.

Eroğlu, H., Çakır, G., Sivrikaya, F., and Akay, A. E.: Using high resolution images and elevation data in classifying erosion risks of bare soil areas in the Hatila Valley Natural Protected Area, Turkey, Stoch. Env. Res. Risk A., 24, 699-704, 2010.

Ezugwu, C.: Sediment Deposition in Nigeria Reservoirs: Impacts and Control Measures, Innovative Systems Design and Engineering, 4, 54-62, 2013.

Godwin, A. M., Gabriel, S., Hodson, M., and Wellington, D.: Sedimentation impacts on reservoir as a result of land use on a selected catchment in Zimbabwe, International Journal of Engineering Science \& Technology, 3, 2011.

Gusso, A. G. A., Veronez, M. R., Robinson, F., Roani, V., and Da Silva, R. C.: Evaluating the thermal spatial distribution signature for environmental management and vegetation health monitoring, International Journal of Advanced Remote Sensing and GIS, 3, 433-445, 2014. 
Hanke, S. H. and Kwok, A. K.: On the measurement of Zimbabwe's hyperinflation, Cato J., 29, 353-364, 2009.

Hoko, Z.: An assessment of quality of water from boreholes in Bindura District, Zimbabwe, Phys. Chem. Earth, 33, 824-828, 2008.

Jang, C., Shin, Y., Kum, D., Kim, R., Yang, J. E., Kim, S. C., Hwang, S. I., Lim, K. J., Yoon, J.-K., and Park, Y. S.: Assessment of soil loss in South Korea based on land-cover type, Stoch. Env. Res. Risk A., 1-15, 1996.

Kamaludin, H., Lihan, T., Ali Rahman, Z., Mustapha, M. A., Idris, W. M. R., and Rahim, S. A.: Integration of remote sensing, RUSLE and GIS to model potential soil loss and sediment yield (SY), Hydrol. Earth Syst. Sci. Discuss., https://doi.org/10.5194/hessd-10-4567-2013, 2013.

Lawson, E. O.: Physico- chemical parameters and heavy metal contents of water from the mangroves swamps of logos lagon, logos, Nigeria, Advances in biological research, 5, 8-21, 2011.

Makwara, E. and Gamira, D.: About to Lose all the Soil in Zaka's Ward 5, Zimbabwe: Rewards of Unsustainable Land Use, European Journal of Sustainable Development, 1, 457-476, 2012.

Mambo, J. and Archer, E.: An assessment of land degradation in the Save catchment of Zimbabwe, Area, 39, 380-391, 2007.

Merritt, W. S., Letcher, R. A., and Jakeman, A. J.: A review of erosion and sediment transport models, Env. Modell. Softw., 18, 761-799, 2003.

Met: Meteorological data, available at: https://www.wmo.int/ datastat/wmodata_en.htmll, last access: 3 March 2015.

Mutowo, G. and Chikodzi, D.: Erosion Hazard Mapping in the Runde Catchment: Implications for Water Resources Management, Journal of Geosciences and Geomatics, 1, 22-28, 2013.

Pettorelli, N., Vik, J. O., Mysterud, A., Gaillard, J.-M., Tucker, C. J., and Stenseth, N. C.: Using the satellite-derived NDVI to assess ecological responses to environmental change, Trends Ecol. Evol., 20, 503-510, 2005.

Renard, K. G., Foster, G. R., Weesies, G. A., McCool, D., and Yoder, D.: Predicting soil erosion by water: a guide to conservation planning with the revised universal soil loss equation (RUSLE), Agriculture Handbook, Washington, 703, 1997.
Rooseboom, A. and Engineers, S. B. C.: Sediment transport in rivers and reservoirs: a Southern African perspective, Water Research Commission, 297/1/92:489, 1992.

Sawunyama, T., Senzanje, A., and Mhizha, A.: Estimation of small reservoir storage capacities in Limpopo River Basin using geographical information systems (GIS) and remotely sensed surface areas: Case of Mzingwane catchment, Phys. Chem. Earth, 31, 935-943, 2006.

Sumi, T. and Hirose, T.: Accumulation of sediment in reservoirs, Water storage, transport and distribution, UNESCO-IHE and EOLSS Publishers Co. Ltd., Paris, France, 224-252, 2009.

Teh, S. H.: Soil erosion modeling using RUSLE and GIS on Cameron highlands, Malaysia for hydropower development, MS, The School for Renewable Energy Science, Iceland, 41 pp.,2011.

USDA: Procedure for computing sheet and rill equation on project areas, Technical Release No. 51 (Geology), U.S. Government Printing Office, Washington, D.C., 1972.

Walling, D. and Fang, D.: Recent trends in the suspended sediment loads of the world's rivers, Global Planet. change, 39, 111-126, 2003.

Whitlow, R.: Mapping erosion in Zimbabwe: a methodology for rapid survey using aerial photographs, Appl. Geogr., 6, 149-162, 1986.

WHO: Guidelines for drinking water quality: Third edition incorporating the first and second addenda volume 1 additions, 2008.

Wischmeier, W. and Smith, D.: Predicting rainfall erosion losses. Agricultural Handbook 537, Agricultural Research Service, United States Department of Agriculture, 1978.

Zinwa, D. R.: Assessment of Surface Water Resources of Zimbabwe and Guidelines for Planning, in: Management, ZINWA Research and Data Department, Ministry of Water Resources Development and Management Harare, Zimbabwe, Harare, 59 pp., 2009.

Zwane, N., Love, D., Hoko, Z., and Shoko, D.: Managing the impact of gold panning activities within the context of integrated water resources management planning in the Lower Manyame Sub-Catchment, Zambezi Basin, Zimbabwe, Phys. Chem. Earth, 31, 848-856, 2006. 